Research Article

\title{
Experimental and Numerical Analysis Study on Loess-Lime Structures Used for Lateral Antiseepage in Deep Collapsible Ground Embankment
}

\author{
Zhengrui Zhang $\mathbb{D}^{1,2,3}$ Siti Jahara Matlan $\mathbb{D}^{1},{ }^{1}$ Lili Zhang $\mathbb{D}^{2,3}$ and Hao Wang $\mathbb{D}^{4}$ \\ ${ }^{1}$ Civil Engineering Programme, Faculty of Engineering, University Malaysia Sabah, Kota Kinabalu 88400, Sabah, Malaysia \\ ${ }^{2}$ College of Civil Engineering, Sichuan University of Science \& Engineering, Zigong, Sichuan 643000, China \\ ${ }^{3}$ Sichuan Province University Key Laboratory of Bridge Non-Destruction Detecting and Engineering Computing, Zigong, \\ Sichuan 643000, China \\ ${ }^{4}$ Gansu Province Urban And Rural Planning Design \& Research Institute Co., Ltd, Lanzhou, China
}

Correspondence should be addressed to Zhengrui Zhang; zzrsuse@sina.com and Siti Jahara Matlan; jahara@ums.edu.my

Received 7 April 2021; Revised 6 July 2021; Accepted 27 July 2021; Published 10 August 2021

Academic Editor: Jorge Branco

Copyright (c) 2021 Zhengrui Zhang et al. This is an open access article distributed under the Creative Commons Attribution License, which permits unrestricted use, distribution, and reproduction in any medium, provided the original work is properly cited.

\begin{abstract}
The focus of this study was to investigate the effect of loess soil treated with lime on the lateral-seepage response. Three groups of box experiments were carried out to study the lateral-seepage effect under different types of loess-lime structures. Automated testing systems were designed to perform experiments and collect data. Additionally, numerical analysis of lateral-seepage impact and embankment settlement was performed. Finally, moisture content and settlement were monitored to quantify lateral-seepage effect results under corresponding loess-lime treatment. Results showed that loess-lime compaction piles and diaphragm wall structures could effectively prevent lateral seepage, and the latter was better. The simulated results are similar to the measured values of the box experiment, which indicates the accuracy of the simulation analysis and further supports the experimental results of this study.
\end{abstract}

\section{Introduction}

Loess is widely distributed worldwide, such as in Asia, Central Europe, Southern Europe, Northern Russia, Midwestern United States, and other places [1]. China is the country with the most extensive loess area in the world. The total area of loess reaches $63.1 \times 104 \mathrm{~km}^{2}$, accounting for $6.6 \%$ of the total land area of China [2]. Loess is divided into collapsible loess and non-collapsible loess [3]. The main feature of collapsible loess is collapse when it encounters water. In a dry state, loess has a specific bearing capacity. However, after experiencing water [4], the cement between the particles is dissolved. The soil tends to be dense under the influence of its weight, and it appears as a collapse in appearance [5]. The collapsibility of the loess has a significant impact on the construction of the project, such as roadbed subsidence [6], soil loss, and so on. These engineering disasters are not uncommon in our current engineering construction [7]; therefore, in the construction of the collapsible loess area, antiseepage and collapsibility must be considered [8]. The standard methods used to eliminate collapsibility include tamping [9], exchange-fill [10], cement mixing pile [11], CFG pile [12], and building seepage prevention structure.

Water is the leading cause of geological disasters in collapsible loess. Studying the soil and water relationship has always been a hot topic in the civil engineering field. Haike Wang and Hui Qian investigated non-Darcy flow in loess at the low hydraulic gradient and researched permeability of remolded loess with different dry densities under saturated permeation [13-15]. Matlan et al. studied SWCC, evaluated four-parameter models' performance, and assessed the 
consistency in determining SWCC [16-18]. Wang et al. researched the mechanisms of Malan loess on the Chinese Loess Plateau and their effects on eroded loess landforms [1]. Ni et al. used SEM analysis of the microstructural of loess and found that the microstructural had a significant impact on loess collapsibility during wetting-drying cycles [19]. Fattah et al. found that the behavior of loess soil is similar to that of collapsible gypseous soil; they often have sufficient void space in their natural state to hold their liquid limit moisture content at saturation. These soils possess high apparent strength at their naturally low moisture content, but they are susceptible to significant reductions in void ratio upon wetting $[20,21]$. But there are less research studies on lateral antiseepage of embankment in this area. Zhu et al. [22] studied the effect of different structures to control lateral seepage and found that loesslime pile and wall could prevent lateral seepage effectively and provide a new ideal for collapsible loess foundation treatment. Niu Ya et al. [23] carried out an indoor model test to study loess-lime compaction pile and cement-soil compaction pile with different pile spacing as the lateral seepage control structure; results showed that cement-soil compaction pile has a better effect on seepage control than lime-soil compaction pile. But both Zhu and Niu they all conducted traditional manual data acquisition experiments and did not use numerical simulations to validate the test results.

The objective of this study was to observe the deformation and collapse of a laboratory-scale experimental loess embankment using a newly designed test system while simultaneously measuring water content, settlement, and collapse. This enabled us to quantify variations in lateral antiseepage control in response to different seepage prevent structures that used loess-lime materials. Additionally, numerical analysis was carried out to compare with lab results; they can prove the accuracy of each other.

\section{Test Materials}

2.1. Test Materials. The local Malan loess and the lime purchased from Gansu Zheng Yang Calcium Industry Co. Ltd. were selected for testing. The Malan loess was first dried and rolled and passed through a $5 \mathrm{~mm}$ sieve for compaction test. After the compaction is completed, to improve the accuracy of the test results, two parts of soil are taken from each sample cylinder to measure the water content in parallel. The compaction test records are shown in Table 1. The relationship curve of dry density and moisture content is shown in Figure 1. We can see that the best moisture content and maximum dry density of loess are $15.8 \%$ and $1.63 \mathrm{~g} / \mathrm{m}^{3}$.

The loess soil samples were prepared according to the optimal water content and dry density, and the permeability coefficient was measured. The test used a triaxial permeameter. The test results are shown in Table 2.

2.2. Sample Preparation. The sample was made of Malan loess and lime in a volume ratio of $3: 7$. Seven groups of samples were prepared with different moisture contents, and
TABLE 1: Loess compaction test results.

\begin{tabular}{llllll}
\hline Water content $\omega(\%)$ & 11.5 & 13.3 & 15.8 & 17.4 & 18.9 \\
Dry density $\rho_{d}\left(\mathrm{~g} / \mathrm{cm}^{3}\right)$ & 1.45 & 1.52 & 1.63 & 1.55 & 1.48 \\
\hline
\end{tabular}

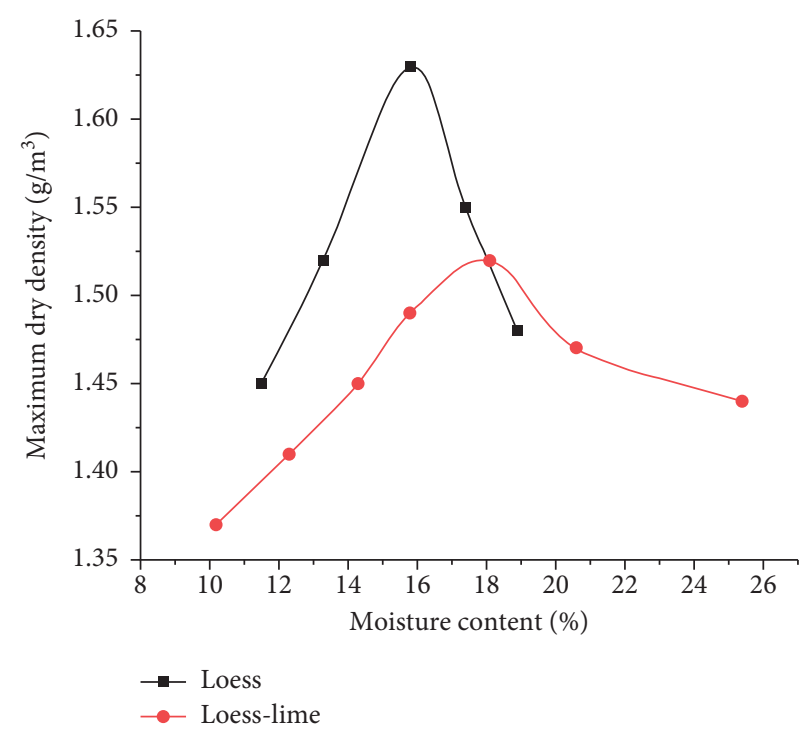

Figure 1: Maximum dry density and moisture relationship curve about loess and loess-lime.

compaction tests were carried out on them to obtain the maximum dry density. The compaction and permeability test records are shown in Table 3. The relationship curve of dry density and moisture content is shown in Figure 1; for loess-lime, the best moisture content and maximum dry density are $18.1 \%$ and $1.52 \mathrm{~g} / \mathrm{m}^{3}$.

The loess-lime sample was prepared according to the maximum dry density and the best water content, and the permeability coefficient was measured. The test was conducted with a triaxial permeameter. The test results of the permeability coefficient of the sample are shown in Table 4:

In Table 4, as the confining pressure changes from $100 \mathrm{kPa}$ to $400 \mathrm{kPa}$ in the permeability test, the permeability coefficient decreases from $7.6 \times 10^{-7} \mathrm{~cm} / \mathrm{s}$ to $6.0 \times 10^{-7} \mathrm{~cm} / \mathrm{s}$, and the rate of change is $21.0 \%$; the change rate of loess-lime permeability coefficient with confining pressure is lower than that of loess. In addition, from the permeability coefficients of loess and loess-lime under different confining pressures, it can be seen that the permeability coefficient of loess is three orders of magnitude higher than that of loesslime, so the permeability coefficient of loess-lime is much lower than that of loess.

\section{Methods}

3.1. Experiment Design. Three types of the roadbed and lateral antiseepage structures were constructed in a $1.2 \mathrm{~m} \times 1.2 \mathrm{~m} \times 1.2 \mathrm{~m}$ (length $\times$ width $\times$ height $)$ metal box, and the box was filled with loess. For antiseepage structures, test A was without treatment, test B was treated with lime pile compaction, and test $\mathrm{C}$ was treated with loess-lime cutoff wall (Figure 2). Three dial gages and nine moisture 
TABLE 2: Loess permeability test results.

\begin{tabular}{lcccc}
\hline Radial pressure $\sigma_{3}(\mathrm{kPa})$ & 100 & 200 & 300 & 400 \\
Permeability coefficient $(\mathrm{cm} / \mathrm{s})$ & $7.4 \times 10^{-4}$ & $5.7 \times 10^{-4}$ & $3.6 \times 10^{-4}$ & $1.5 \times 10^{-4}$ \\
\hline
\end{tabular}

TABLE 3: Loess-lime compaction test results.

\begin{tabular}{lllllll}
\hline Water content $\omega(\%)$ & 10.2 & 12.3 & 14.3 & 15.8 & 18.1 & 20.6 \\
Dry density $\rho_{d}\left(\mathrm{~g} / \mathrm{cm}^{3}\right)$ & 1.37 & 1.41 & 1.45 & 1.49 & 1.52 & 1.47 \\
\hline
\end{tabular}

TABLE 4: Loess-lime (volume ratio: 3:7) penetration test results.

\begin{tabular}{lcccc}
\hline Radial pressure $\sigma_{3}(\mathrm{kPa})$ & 100 & 200 & 300 & 400 \\
Permeability coefficient $(\mathrm{cm} / \mathrm{s})$ & $7.6 \times 10^{-7}$ & $6.4 \times 10^{-7}$ & $6.4 \times 10^{-7}$ & $6.0 \times 10^{-7}$ \\
\hline
\end{tabular}
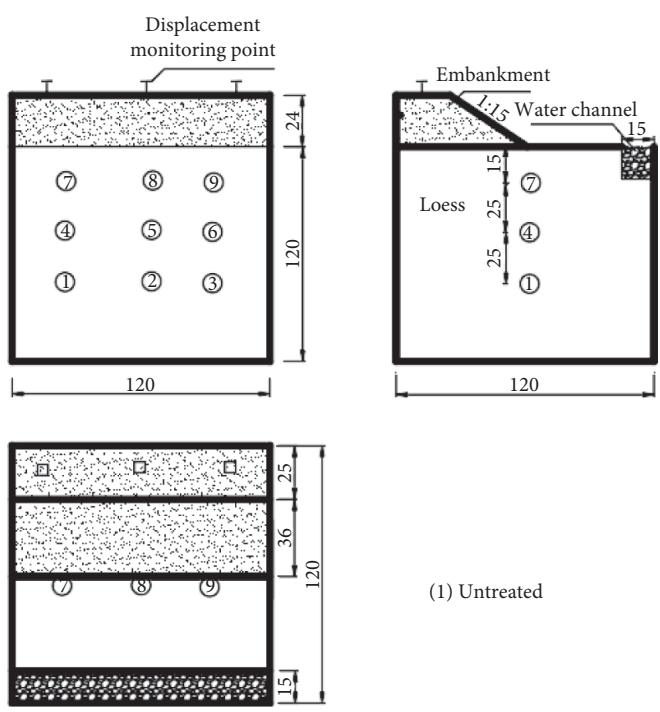

(1) Untreated
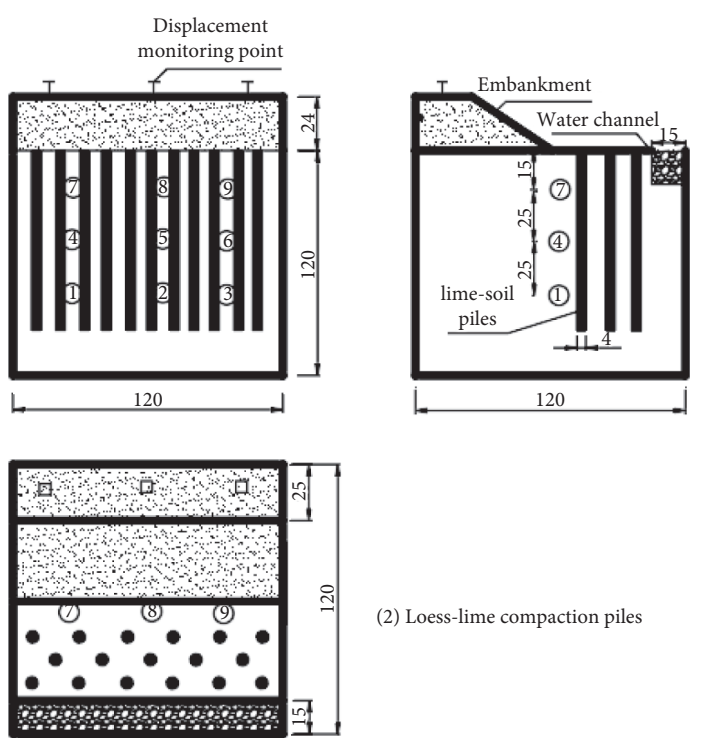

(2) Loess-lime compaction piles
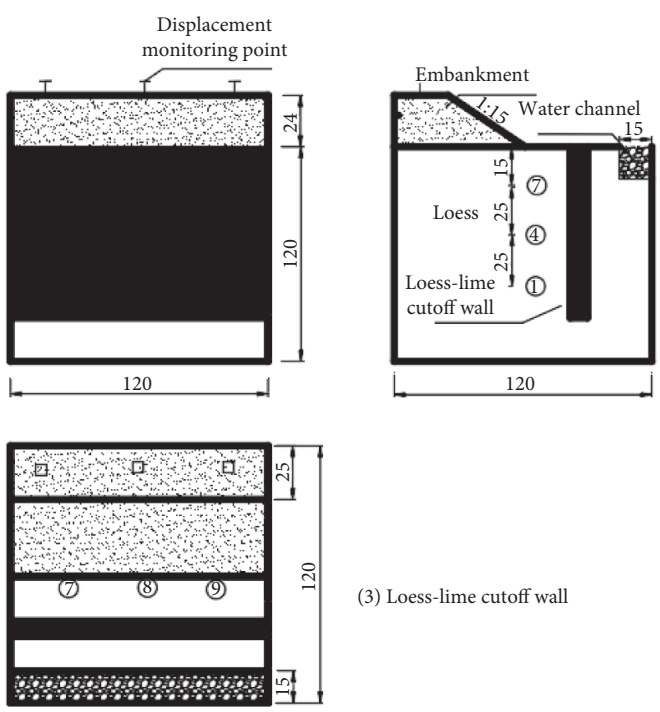

(3) Loess-lime cutoff wall

Figure 2: Schematic diagram of tests A, B, and C. Note: points 1 to 9 are the locations of moisture sensors.

content sensors (Long Kong, China) were installed inside. The specifications and accuracy of moisture content sensors are shown in Table 5. The sensors were connected to a data logger (Decagon, USA), which correlated with the computer. The sensors were calibrated before each experiment. A water level sensor was installed in the water channel to monitor the water level controlled by an electromagnetic valve (ELECALL, China). They are all connected to the computer via the controller configuration (Figure 3). Through this lab system, the water head could be controlled at a designed level 
TABLE 5: Specifications of moisture content sensors.

\begin{tabular}{lccccc}
\hline Measurement range & Accuracy & IP level & Power supply mode & \multicolumn{2}{c}{ Work environment } \\
& & & Temperature & Humidity \\
\hline $0 \%-100 \%$ & \pm 3 & IP 68 & DC5 24 V & $-50^{\circ} \sim 80^{\circ}$ & $0 \%-100 \%$ \\
\hline
\end{tabular}

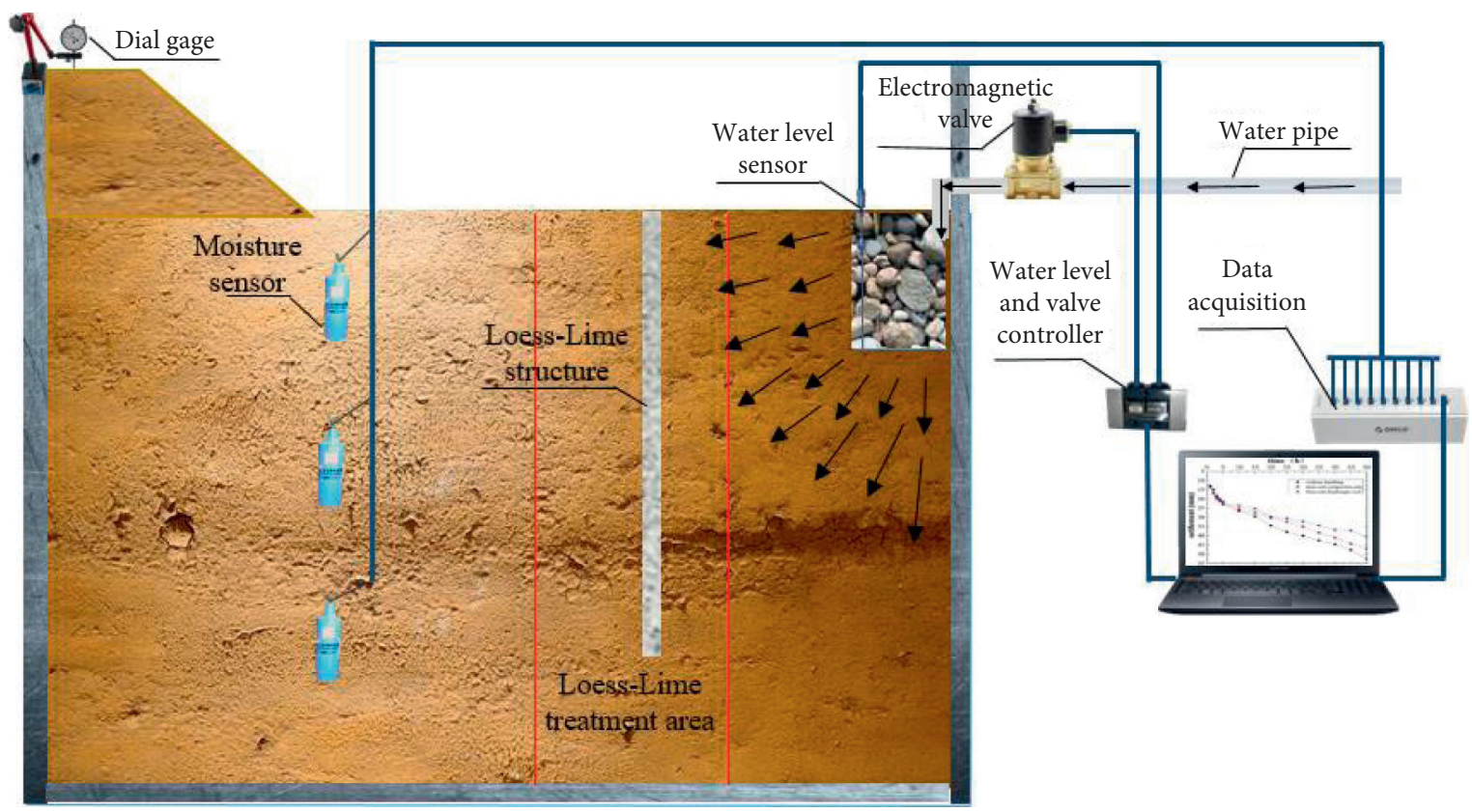

Figure 3: Test system and location of moisture sensor.

automatically, and all the data were also collected voluntarily at the frequency of ten minutes once.

3.2. Experiment Process. The density of loess filled in the box was controlled in $80 \%$ of the maximum dry density $(1.63 \mathrm{~g} /$ $\mathrm{m}^{3}$. The schematic diagram of three test conditions is shown in Figure 3. For situation A, the loess-lime compaction piles were constructed in a distance of $2.5 d$, where $d=4 \mathrm{~cm}$; the piles are hammered into holes by hollow steel pipes, filled with the loess-lime sample prepared before layered ramming (Figure 4(a)). After the model was filled for situation B, the loess-lime cutoff wall was excavated according to the design position and depth and then filled with layered loess-lime, vibrated, and compacted (Figure 4(b)). During the process, moisture sensors were installed in the designed position (Figure 4(c)). The bags filled with steel grit were placed on the top of roadbed to apply a vertical pressure to the subgrade, and the load was $4 \mathrm{kPa}$ after the model was converted (Figure 4(d)). Three dial indicators were set up to determine the roadbed settlement. After the model was completed, the computer controlled the water level sensor and electromagnetic valve, and a 50-hour penetration test was processed.

\section{Result and Analysis}

4.1. Moisture Content. Figure 5 describes the moisture change of the nine monitors with time. As time progresses, water content increased. The moisture increase rate of test A was the highest, and the moisture increase rate of test $\mathrm{C}$ was the lowest. This is because the sample was mixed with lime and soil, and chemical reaction would take place when the lime and loess met water, and new substances generated such as calcium silicate hydrate which could reduce the permeability coefficient. In test A, the loess-lime pile also dramatically improves soil compactness between piles, thus reducing the permeability coefficient in this area. For test C, the loess-lime cutoff wall effectively prevented the infiltration of water. Therefore, the loess-lime barrier wall had the most noticeable effect.

The data collected by moisture sensors at the bottom of the box showed that the water content increase rate was slower than that near the water channel. The rate of penetration is inversely proportional to distance. And the closer the moisture sensor was to the wall of the model box, the higher the data of permeability coefficient was. Because the model box was assembled with a steel plate, a layer of the plastic liner was laid inside the steel plate to prevent the water from passing away before filling soil. In the later stage of model filling, it was inevitable that there would be tiny gaps between the soil sample and the plastic liner. In the process of the permeability test, the water will pass through the gap first, resulting in the high moisture content of the soil near the edge of the box, so the data collected from the middle sensors were more accurate.

4.2. Embankment Settlement. After 5 hours, the settlement of the three tests was the same, and the settlement rate was similar at each time point before 5 hours (Figure 6). At 5 

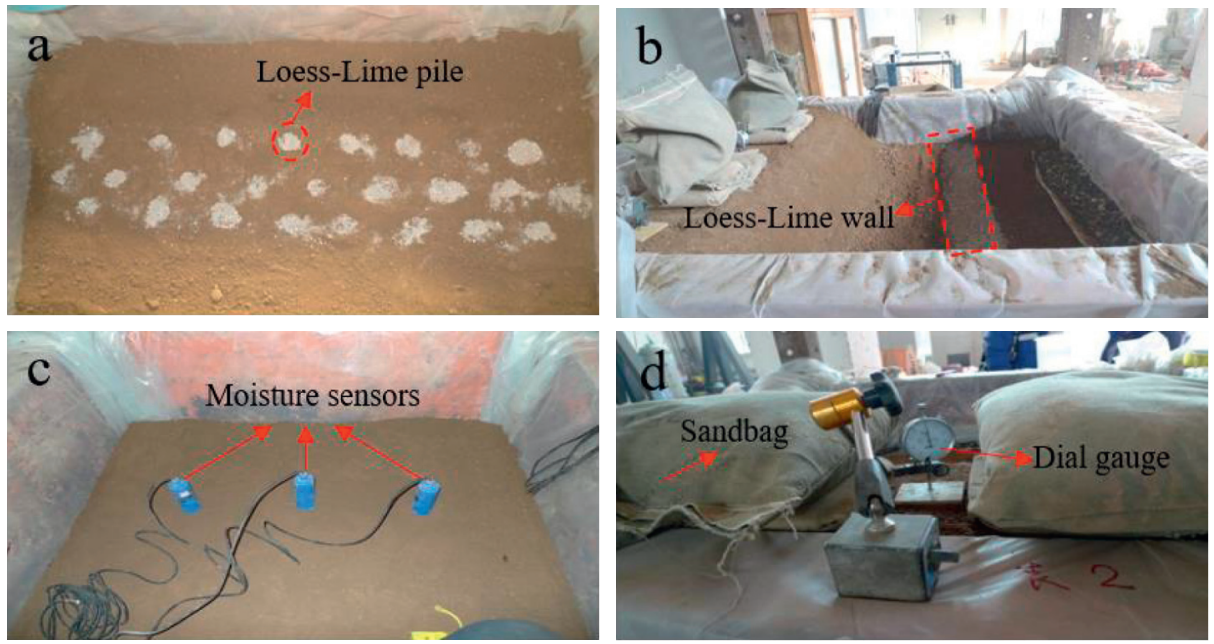

FIGURE 4: Filling diagram of the model box. (a) Loess-lime compaction pile. (b) Diaphragm wall. (c) Moisture sensor. (d) Subgrade loading and dial indicator.

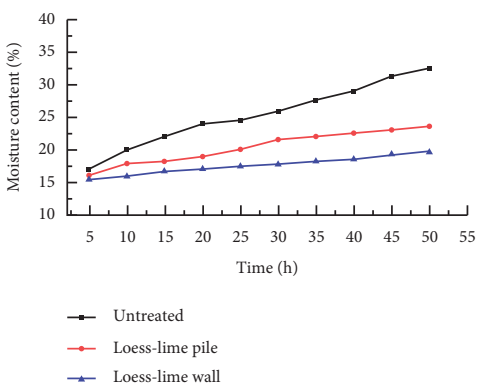

(a)

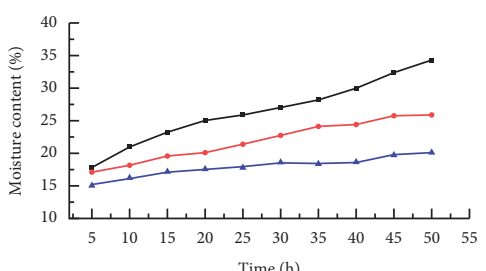

$$
\begin{aligned}
& \rightarrow \quad \text { Untreated } \\
& \rightarrow \quad \text { Loess-lime pile } \\
& \rightarrow \quad \text { Loess-lime wall }
\end{aligned}
$$

(d)

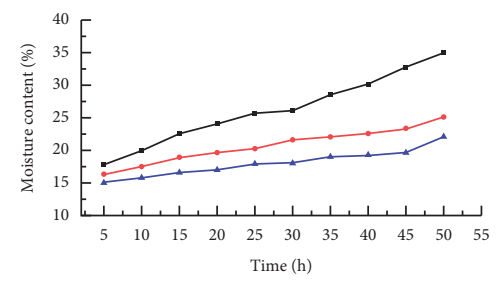

$$
\begin{aligned}
& \rightarrow \text { Untreated } \\
& \rightarrow \text { Loess-lime pile } \\
& \rightarrow \text { Loess-lime wall }
\end{aligned}
$$

(g)


$$
\begin{aligned}
& \rightarrow \text { Untreated } \\
& \rightarrow \quad \text { Loess-lime pile } \\
& \rightarrow \quad \text { Loess-lime wall }
\end{aligned}
$$

(b)

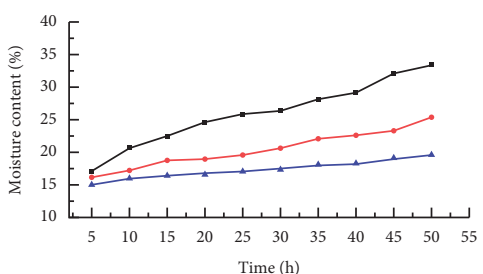

$\rightarrow$ Untreated

-- Loess-lime pile

- Loess-lime wall

(c)

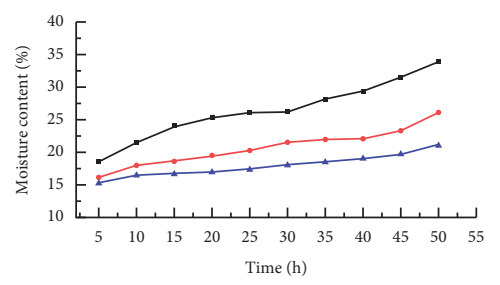

$\rightarrow$ Untreated

$\rightarrow$ Loess-lime pile

$\star$ Loess-lime wall

(e)

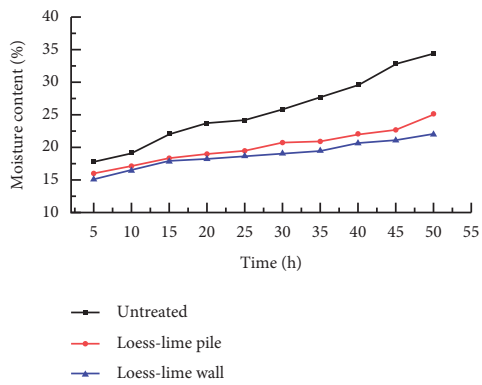

(h)

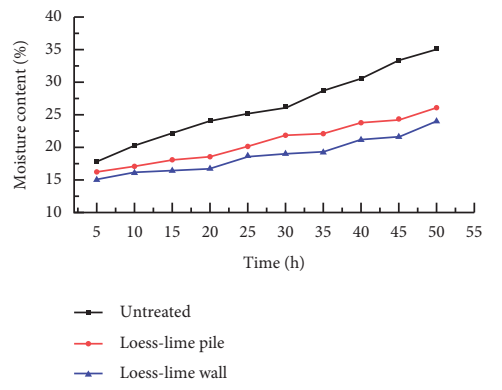

(i)

Figure 5: Changes in water content of each monitoring point over time. (a) Sensor no. 1. (b) Sensor no. 2. (c) Sensor no. 3. (d) Sensor no. 4. (e) Sensor no. 5. (f) Sensor no. 6. (g) Sensor no. 7. (h) Sensor no. 8. (i) Sensor no. 9. 


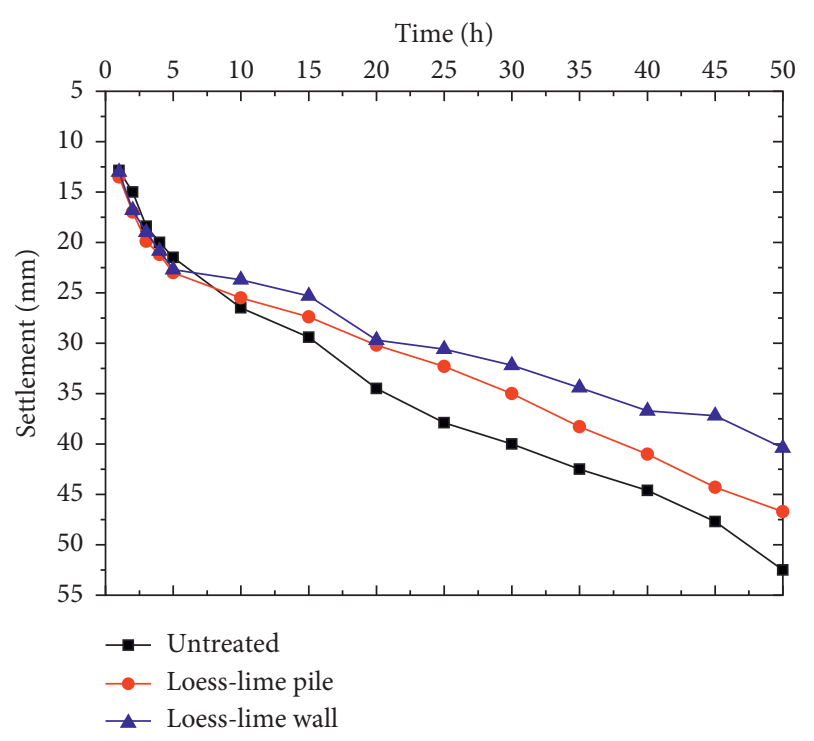

FIgURE 6: Subgrade settlement changes with time.

hours, the settlement of test A was $21.55 \mathrm{~mm}$, test B was $23.00 \mathrm{~mm}$, and test $\mathrm{C}$ was $22.70 \mathrm{~mm}$, and the curvature of the curves for $0 \sim 5$ hours was also close to the same (Figure 6). The reason for this is that during this time section, the water had not fully penetrated the root of the roadbed. At this time, the collapsibility of the loess had little effect on the settlement. The main reason for the settlement was the compactness of the foundation and the roadbed when filling. To observe the water penetration more intuitively, the density control was relatively low when building the model, which was somewhat different from the actual natural density. Due to its weight, the roadbed had undergone a large settlement $[22,23]$.

After 5 hours, the consolidation settlement was completed. From the 5th hour to 50 hours, the subsequent settlement was mainly caused by the collapse of loess with water infiltration in the road base. With the increase of infiltration time, the water content of the soil at the bottom of the subgrade increased continuously, and the rise in the moisture content leads to the collapsibility of the soil, which leads to the settlement of the subgrade. At this stage, the law of the settlement curve was consistent with the water content change curve obtained before (Figure 5). It can be seen from Figure 6 that due to the different antiseepage structures of the three groups of the test, their blocking effects on moisture were also different. The most direct reflection was the roadbed's settlement, and test A's settlement was the largest; test C's settlement was the smallest. The final settlement of test A, B and C was $52.50 \mathrm{~mm}, 46.70 \mathrm{~mm}$ and $40.44 \mathrm{~mm}$ respectively.

4.3. Collapse and Crack. Affected by permeation, collapse and cracks firstly appeared from top to bottom near the water channel of the model box, and the formation rate of collapse and crack slowed down when water reached the treatment area. After 30 hours, the cracks near the flume became significantly more significant, and the depth also deepened; transverse cracks appeared near the water channel (Figure 7(b)). Since the cracks were expanded from top to bottom, the expansion of the cracks would lead to the increase of the water content in the area, and the increase of the water content would promote the collapse, so collapse firstly appeared near the water channel (Figure 7). But in the loess-lime treated area, the loess-lime structure could effectively reduce permeability, because $\mathrm{SiO}_{2}$ and $\mathrm{Al}_{2} \mathrm{O}_{3}$ in loess could react with lime and form new materials, which could improve the impermeability [24].

$$
\begin{gathered}
\mathrm{xC}_{\mathrm{a}}(\mathrm{OH})_{2}+\mathrm{S}_{\mathrm{i}} \mathrm{O}_{2}+\mathrm{mH}_{2} \mathrm{O}=\mathrm{xC}_{\mathrm{a}} \mathrm{O} \cdot \mathrm{S}_{\mathrm{i}} \mathrm{O}_{2} \cdot \mathrm{nH}_{2} \mathrm{O} \\
\mathrm{yC}_{\mathrm{a}}(\mathrm{OH})_{2}+\mathrm{Al}_{2} \mathrm{O}_{3}+\mathrm{mH}_{2} \mathrm{O}=\mathrm{yC}_{\mathrm{a}} \mathrm{O} \cdot \mathrm{Al}_{2} \mathrm{O}_{3} \cdot \mathrm{nH}_{2} \mathrm{O}
\end{gathered}
$$

\section{Numerical Analysis}

5.1. Seepage Numerical Analysis with GeoStudio. The lab seepage test was modeled and analyzed by GeoStudio software. The initial model was established according to the size of the model box (Figure 8). The light green part in the figure was the area treated by loess-lime. The blue arrow showed the location of the immersion tank in the model test, where water will permeate vertically and horizontally. The bottom and side boundary conditions were set as zero of total flow $(Q=0)$, consistent with the indoor model test. According to experiment and experience, physical parameters of loess and loess-lime are obtained, which are shown in Table 6.

Corresponding to the indoor model test, the water content images of three groups of tests in different periods were extracted for comparative analysis to observe water content changes under different constructions. From Figure 9, we can see that in the first 10 hours, the wetting front had not yet crossed the treatment area, the main settlement of the roadbed in this stage was caused by self consolidation. After 10 hours, wetting front near the bottom of the subgrade and loess collapsibility occurred at the bottom, which aggravated roadbed settlement. The settlement and the curve slope were close to equal (Figure 5). After 20 hours, the settlement difference of the three tests increased continuously. The slope of test A was the largest, while that of test C was the smallest.

The penetration rate slowed significantly as it passed through the treated area. The wetting front moved from right to left in the horizontal direction and from up to bottom in the vertical direction. So, cracks and collapses may appear in the direction of the wetting front. It was similar to the lab test results. The results obtained from the numerical simulation are consistent with the conclusions obtained from previous indoor model tests. Among the three groups of tests, the infiltration in test $C$ was the slowest, followed by test $\mathrm{B}$. In test $\mathrm{A}$, the infiltration rate was the fastest because no antiseepage treatment was carried out. Therefore, it can be concluded that the antiseepage effect of the loess-lime cutoff wall was better than that of the lime-soil compacted pile. 

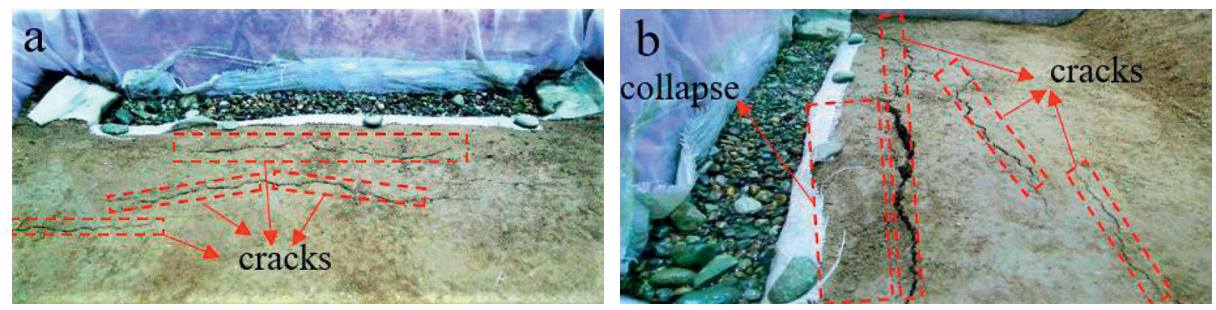

Figure 7: Collapse and crack after permeation. (a) 10 hours. (b) 30 hours.

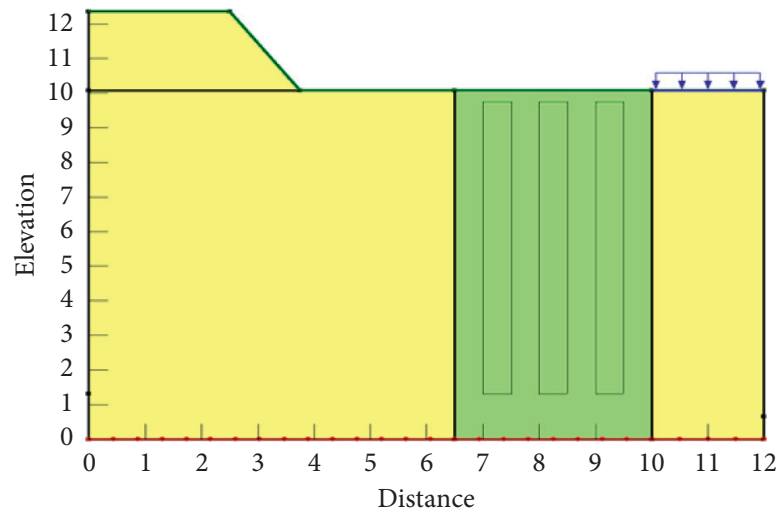

FIgURE 8: Initial model diagram.

TABle 6: Parameters used in the model.

\begin{tabular}{lccccc}
\hline Types of soil & $\rho\left(\mathrm{g} / \mathrm{cm}^{3}\right)$ & $\mathrm{C}(\mathrm{kPa})$ & $\varphi\left(^{\circ}\right)$ & Permeability coefficient $(\mathrm{cm} / \mathrm{s})$ & $7.4 \times 10^{-4}$ \\
\hline Loess & 1.63 & 15 & 10 & $7.6 \times 10^{-7}$ & 35 \\
Loess-lime & 1.52 & 125 & 20 & 20 \\
\hline
\end{tabular}

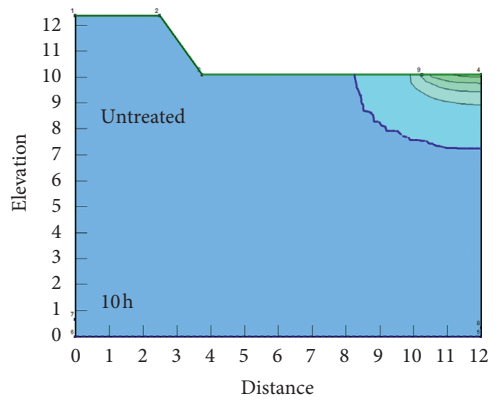

(a)

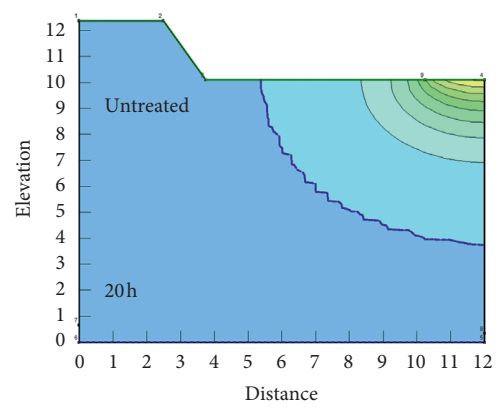

(d)

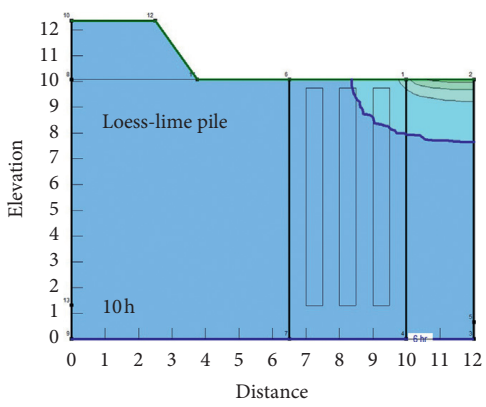

(b)

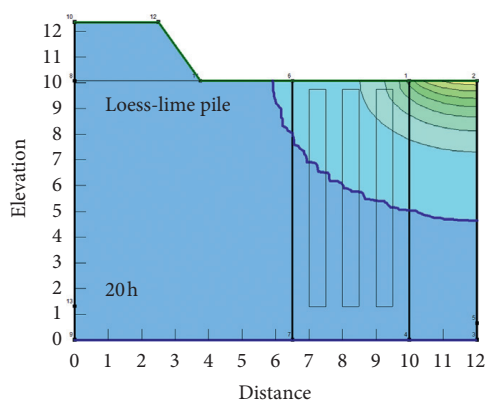

(e)

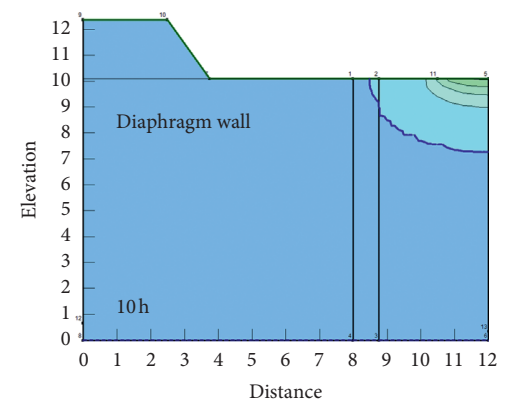

(c)

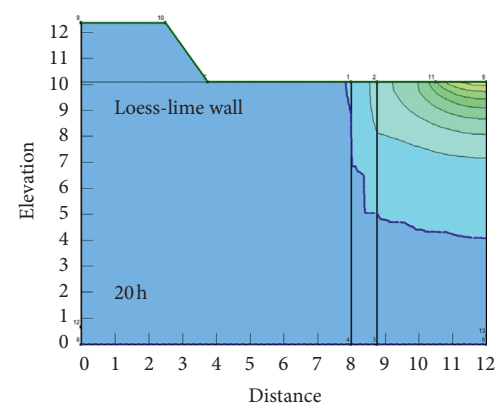

(f)

FIgURE 9: Continued. 


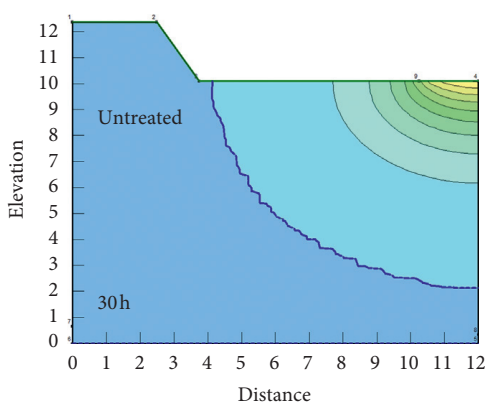

(g)

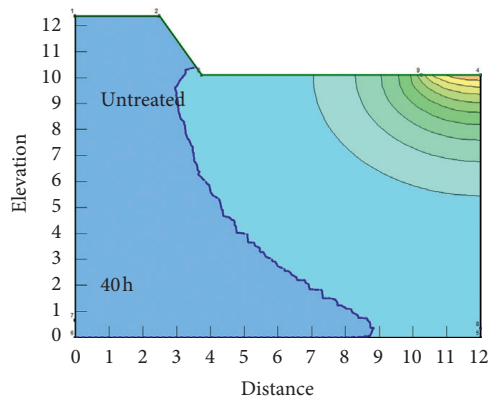

(j)

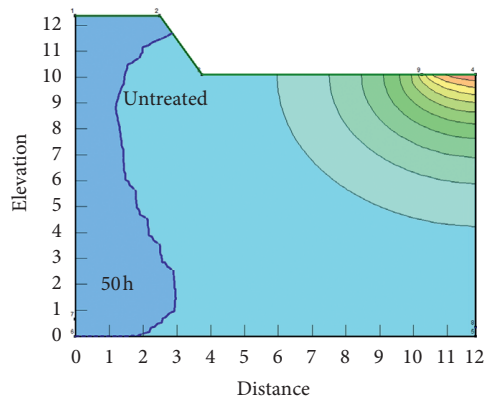

(m)

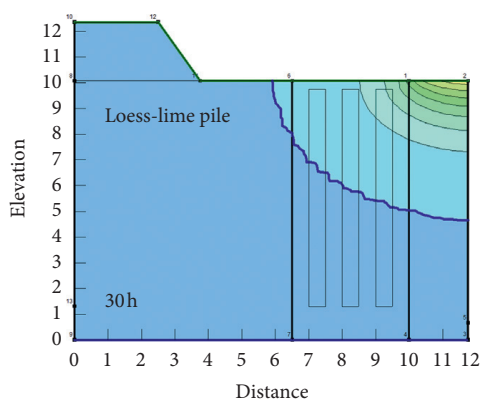

(h)

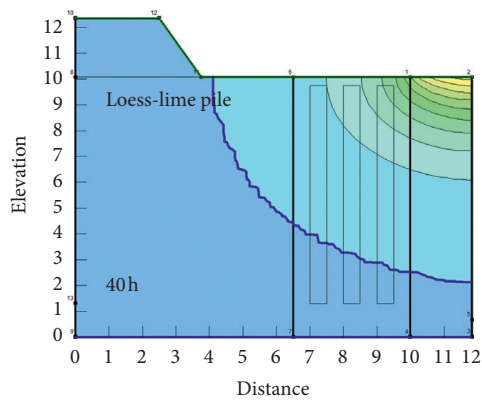

(k)

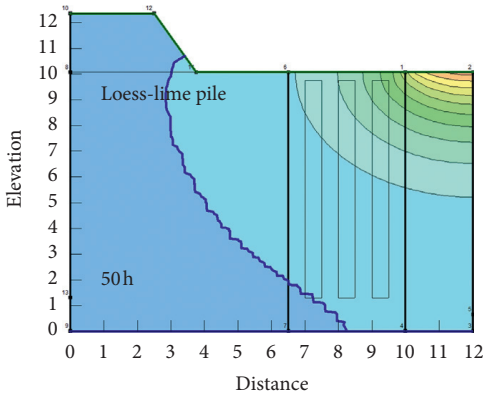

(n)

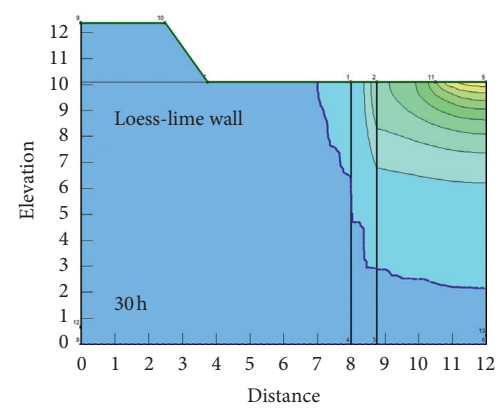

(i)

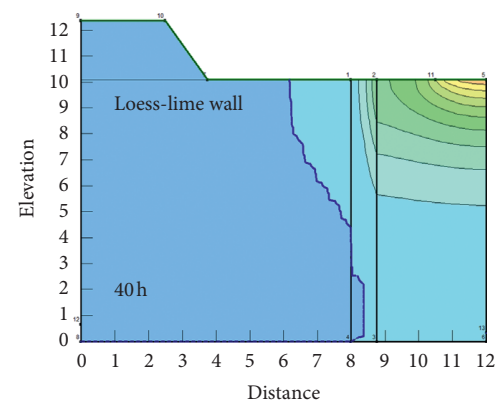

(1)

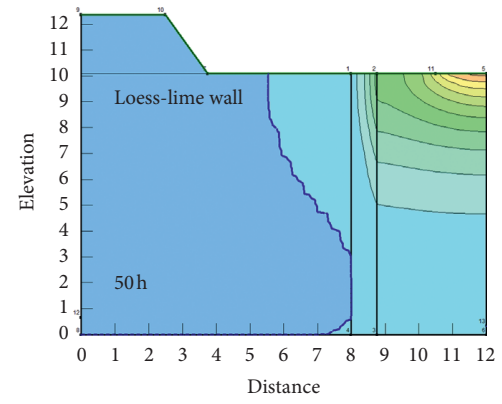

(o)

FIGURE 9: GeoStudio numerical analysis results.

5.2. Roadbed Settlement Numerical Analysis with FLAC-2D. FLAC-2D was used to numerically analyze the settlement of roadbed, and parameters are shown in Table 7.

According to the Mohr-Coulomb model, parameters $K$ and $G$ can be defined as follows:

$$
\begin{aligned}
& K=\frac{E}{3(1-2 \nu)}, \\
& G=\frac{E}{2(1+\nu)} .
\end{aligned}
$$

The dead load $\left(g=9.81 \mathrm{~kg} / \mathrm{m}^{2}\right)$ and the sandbag load $(\sigma=4 \mathrm{kPa})$ were applied to the model. The effect of the load caused the settlement of the foundation, and the surface beyond the embankment slope has some uplift deformation,
TABLe 7: Loess parameters used in the model.

\begin{tabular}{lcccc}
\hline$\rho\left(\mathrm{g} / \mathrm{cm}^{3}\right)$ & $\mathrm{E}(\mathrm{MPa})$ & $\lambda$ & $\mathrm{C}(\mathrm{kPa})$ & $\varphi\left(^{\circ}\right)$ \\
\hline 1500 & 8 & 0.35 & 15 & 10 \\
\hline
\end{tabular}

but it was small and gradually decreased with the increase of the distance from the slope (Figure 10(b)).

From Figure 10(a), we can see that the maximum settlement of the roadbed was $18 \mathrm{~cm}$, and the most significant displacement was $20 \mathrm{~cm}$ in the lab experiment before the wetting front reached the bottom of the roadbed. Thus, although the lab and numerical results were essential close, the differences are unavoidable due to the error existence of precision control in model filling. Moreover, the FLAC software could not simulate the dynamic effect of infiltration on the slope, so only the self-weight and additional load were considered in numerical analysis. 


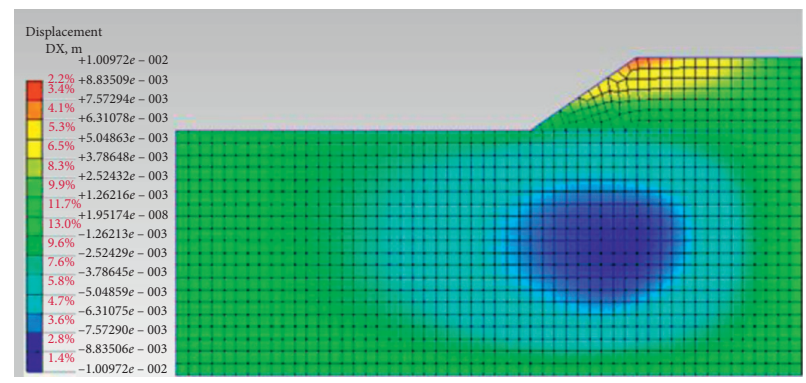

(a)

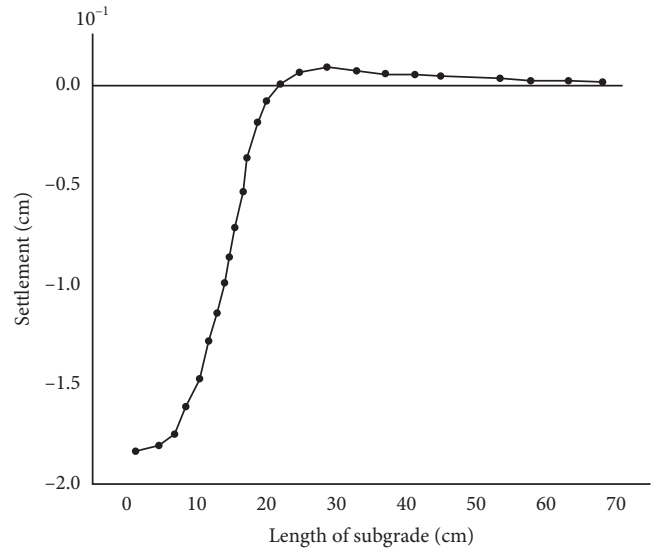

(b)

Figure 10: FLAC-2D numerical analysis results. (a) Foundation settlement curve. (b) Foundation settlement cloud map.

\section{Conclusions}

In the paper, three lab experiments were designed and processed to quantitatively analyze the effect of loess-lime structures on lateral antiseepage in loess ground embankment. In addition, numerical analysis was also carried out to compare with the lab test results. The significant findings of this research are summarized as follows:

(1) Loess-lime compaction piles and loess-lime cutoff walls can effectively improve the ability of lateral antiseepage in deep collapsible loess ground embankment. Loess can react with lime to produce calcium carbonate, which will effectively prevent water penetration. The loess-lime pile also dramatically improves soil compactness between piles, thus reducing the permeability coefficient in this area. For test $\mathrm{C}$, the loess-lime cutoff wall effectively prevented the infiltration of water. Therefore, the loess-lime barrier wall had the most noticeable effect.

Compared with the former, the effect of lime soil pile was relatively poor, but compared with untreated conditions, it still had certain effect; in the final measurement data, test $\mathrm{C}$ was 0.7 times that of test $\mathrm{A}$, and test $\mathrm{B}$ was 0.9 times as much as test $\mathrm{A}$.

(2) The roadbed settlement was obviously reduced, due to the lateral impermeability of the loess-lime structures. Especially for test C, the settlement was the smallest after 50 hours of extreme experiment.

Moisture content and settlement were monitored to quantify the result of lateral-seepage effect under corresponding loess-lime treatment.

(3) Numerical analysis of lateral-seepage effect and embankment settlement was performed. The results showed that the structures of loess-lime pile and cutoff wall could effectively prevent lateral seepage and the effect was significant. The simulated results are similar to the measured values of the box experiment, which indicates the accuracy of the simulation analysis and further supports the experimental results of this study.

\section{Data Availability}

The experiment data used to support the findings of this study are available from the corresponding author upon request.

\section{Conflicts of Interest}

The authors declare that they have no conflicts of interest.

\section{Acknowledgments}

This study was supported by Sichuan University of Science \& Engineering (grant no. 2015RC39) and Opening Project of Sichuan Province University Key Laboratory of Bridge NonDestruction Detecting and Engineering Computing (grant nos. 2021QYJ01 and 2021QYJ02).

\section{References}

[1] L. Wang, X.-A. Li, L.-C. Li et al., "Characterization of the collapsible mechanisms of malan loess on the Chinese loess plateau and their effects on eroded loess landforms," Human and Ecological Risk Assessment: An International Journal, vol. 26, no. 9, pp. 2541-2566, 2020.

[2] J. Zhao, X. Luo, Y. Ma, T. Shao, and Y. Yue, "Soil characteristics and new formation model of loess on the Chinese loess plateau," Geosciences Journal, vol. 21, no. 4, pp. 607-616, 2017, -06-01.

[3] L. Wang, S. Shao, and F. She, "A new method for evaluating loess collapsibility and its application," Engineering Geology, vol. 264, 2020 -11-02, Article ID 105376.

[4] Y. Li, W. Zhang, S. He, and A. Aydin, "Wetting-driven formation of present-day loess structure," Geoderma, vol. 377, Article ID 114564, 2020.

[5] P. Li, S. Shao, T. Xiao, and D. Zhu, "Pore-size distribution evolution of intact, compacted, and saturated loess from China during consolidation and shearing," Advances in Civil Engineering, vol. 202114 pages, 2021, -02-19, Article ID 6644471.

[6] X. Jin, T.-H. Wang, Z.-K. Zhao, L. Zhang, and Y.-Z. Hao, "Collapse potential of loess under unloading effect," Advances 
in Civil Engineering, vol. 2021, Article ID 6617228, 11 pages, 2021.

[7] Y. Wu, K. Zhang, L. Fu, J. Liu, and J. He, "Performance of cement-soil pile composite foundation with lateral constraint," Arabian Journal for Science and Engineering, vol. 44, pp. 4693-4702, 2018.

[8] C. Gao, G. Du, S. Liu, D. Zhang, K. Zhang, and B. Zeng, "Field study on the treatment of collapsible loess using vibratory probe compaction method," Engineering Geology, vol. 274, Article ID 105715, 2020.

[9] Y.-c. Zhang, Y.-g. Yao, A.-g. Ma, and C.-1. Liu, "In situtests on improvement of collapsible loess with large thickness by down-hole dynamic compaction pile," European Journal of Environmental and Civil Engineering, vol. 24, no. 2, pp. 156-170, 2017.

[10] R. Jian, N. Fujun, N. Yonghong, and L. Huachina, “Analysis on the effect of replacing-soil method on inhibiting frost heave of railway roadbed in seasonal frozen soil," Railway Science, vol. 32, no. 5, pp. 1-7, 2011.

[11] W. Zhong Yi, F. Zi Cong, Z. Li Juan, and W. Zhao bin, "Applied research on slope reinforcement with cement mixing pile in deep soft soil foundation pit," IOP Conference Series: Earth and Environmental Science, vol. 570, Article ID 032037, 2020.

[12] B. U. Uge and Y.-C. Guo, "CFG pile composite foundation: its engineering applications and research advances," Journal of Engineering, vol. 2020, pp. 1-26, Article ID 5343472, 2020.

[13] H. Wang, H. Qian, and Y. Gao, "Non-darcian flow in loess at low hydraulic gradient," Engineering Geology, vol. 267, 2020 -03-01, Article ID 105483.

[14] H. Wang, H. Qian, Y. Gao, and Y. Li, "Classification and physical characteristics of bound water in loess and its main clay minerals," Engineering Geology, vol. 265, 2020 -02-01, Article ID 105394.

[15] P. Xu, Q. Zhang, H. Qian, W. Qu, and M. Li, "Microstructure and permeability evolution of remolded loess with different dry densities under saturated seepage," Engineering Geology, vol. 282, Article ID 105875, 2021.

[16] S. J. Matlan, S. Abdullah, R. Alias, and M. Mukhlisin, "Effect of working rainfall and soil water index on slope stability in Ranau, Sabah," International Journal of Civil Engineering \& Technology, vol. 9, no. 7, pp. 1331-1341, 2018.

[17] S. J. Matlan, M. R. Taha, and M. Mukhlisin, "Assessment of model consistency for determination of soil-water characteristic curves," Arabian Journal for Science and Engineering, vol. 41, no. 4, pp. 1233-1240, 2016.

[18] S. J. Matlan, M. Mukhlisin, and M. R. Taha, "Performance evaluation of four-parameter models of the soil-water characteristic curve," Science World Journal, vol. 2014, Article ID 569851, 12 pages, 2014.

[19] W.-k. Ni, K.-z. Yuan, X.-f. Lü, and Z.-h. Yuan, “Comparison and quantitative analysis of microstructure parameters between original loess and remoulded loess under different wetting-drying cycles," Scientific Reports, vol. 10, no. 1, p. 5547, 2020.

[20] M. Y. Fattah, I. H. Obead, and H. A. Omran, "A Study on leaching of collapsible gypseous soils," International Journal of Geotechnical Engineering, vol. 2019, Article ID 1647664, 11 pages, 2019.

[21] M. Y. Fattah, M. K. Hameedi, M. K. Hameedi, and M. F. Aswad, "Determination of collapse potential of gypseous soil from field and laboratory tests," Diyala Journal of Engineering Sciences, vol. 10, no. 2, pp. 75-85, 2017.
[22] J. Zhu, X. Wang, D. Jiang, and Z. Zhang, "Model experimental research on structure of lateral seepage control in collapsible loess foundation," Journal of Engineering Geology, vol. 25, pp. 330-335, 2017.

[23] Q. Niu Ya, X. Wang, J. Zheng, D.-J. Jiang, D. Liu, and P. Jiang, "Experimental research on antiseepage effect of new embankment structure of lateral-constraint and seepage control," Rock and Soil Mechanics, vol. 36, pp. 1000-7598, 2015.

[24] I. Zimmermann, S. Filser, A. Mordhorst, H. Fleige, and R. Horn, "Structural stabilization of soil backfill with quicklime," Journal of Plant Nutrition and Soil Science, vol. 182, no. 4, pp. 578-585, 2019. 